\title{
The environmental impact of the reconstruction and development of the coastal marine transport infrastructure
}

\author{
Yuriy Dreizis ${ }^{1,}{ }^{*}$, Elena Bondareva ${ }^{1}$ and Galina Vershinina $^{1}$ \\ ${ }^{1}$ Sochi State University, 26-A Sovietskaya str., Sochi, 354000, Russia
}

\begin{abstract}
The coastal marine transport is one of the important components defining development of all Black Sea coast of Russia. Questions of need of restoration of coastal passenger traffic within the coast of Greater Sochi in connection with intensive development of tourism in Krasnodar Region of Russia and the questions of the organization of the transport communication between a coastal towns and settlements are considered. Need of further implementation of the program of reconstruction and construction of port points (moorings) and objects of coastal transport infrastructure in the Sochi region and in all Black Sea coast of Russia is shown. The analysis of a problem of environmental protection, which can arise at implementation of the project of reconstruction and development of coastal sea transport infrastructure in the Sochi region, is made. Possible ways of their solution for reduction of impacts on the environment are proposed. Introduction of the program of development of objects of coastal transport in the region, taking into account environment will contribute to sustainable development of the region.
\end{abstract}

\section{Introduction}

The coastal zone is one of its major components of appeal of the region throughout the last century. It is actively used in recreational and tourist activity, for beach rest, and the coastal region first is considered as the sea resort.

The feature of an economical geographical location of Sochi and all Black Sea coast of Russia causes existence in the region of a large number of objects of the tourist sphere and objects which activity is aimed at providing steady prospects of development of a tourist component of the region - fundamentals of its economy.

The coastal marine transport is one of important components, also as well as tourism, defining development of all Black Sea coast.

Coasting shipping, passenger traffic on local coastal lines, the marine cruise transport were widespread along all Black Sea coast of the Soviet Union.

Passenger traffic on local lines successfully functioned until 90th years of the last century. It covered all Black Sea coast of the Soviet Union from Batumi to Odessa and Izmail, using small vessels and "Comet" hydrofoils.

\footnotetext{
${ }^{*}$ Corresponding author: Yurid2006@yandex.ru
} 
Hydrofoils which making interregional transportations, regularly transported passengers from Sochi to Anapa, Gelendzhik, Yalta, Sukhumi and Batumi with visit of all main coastal cities and large settlements on the coast. Coastal seaports of the Black Sea coast were bases of system of local passenger lines. This system covered, especially during the summer resort period, practically all large settlements on the coast of the Caucasus, the Crimea, Ukraine, Abkhazia and Adjara.

The port of Sochi is a not freezing port, and navigation lasts all the year round. The water area of the Sochi sea trade port includes water areas of the main port points (moorings) Adler, the Resort town, Khosta, Loo and Lazarevskoye. The territory of the Sochi port includes 27 sites, and water areas of sea terminals (moorings) - 15 sites.

The system of sea passenger traffic on local lines of Greater Sochi successfully functioned till 90th years of the last century and served up to 1,5 million passengers a year. The passenger turnover of the local lines passing through port points (moorings) of Greater Sochi made from 5 to 80 thousand passengers a year for each port point (mooring). Capacity and a passenger traffic in the largest port points of the Sochi region, such as Adler, Khosta and Lazarevskoye, totally exceeded 200 thousand people in a year (fig. 1).

This type of transport and at the same time recreational services was almost completely liquidated in connection with essential reduction of tourist flow and number of tourists in the next years. Moorings of local lines in the region came to desolation. Ten moorings in connection with critical condition were dismantled.

Tourist flow to the region began to increase significantly in 2008 and 2009 in connection with growth of economy of Russia. The number of vacationers near Greater Sochi exceeded 4 million people annually. At the same time, vessels of coastal swimming transported only several thousands of people.

It was directly connected with destruction of coastal sea transport infrastructure, including port points and piers. In port points on suburban lines, piers and moorings with a wooden flooring functioned generally. They were fragile and after storm demanded repair.

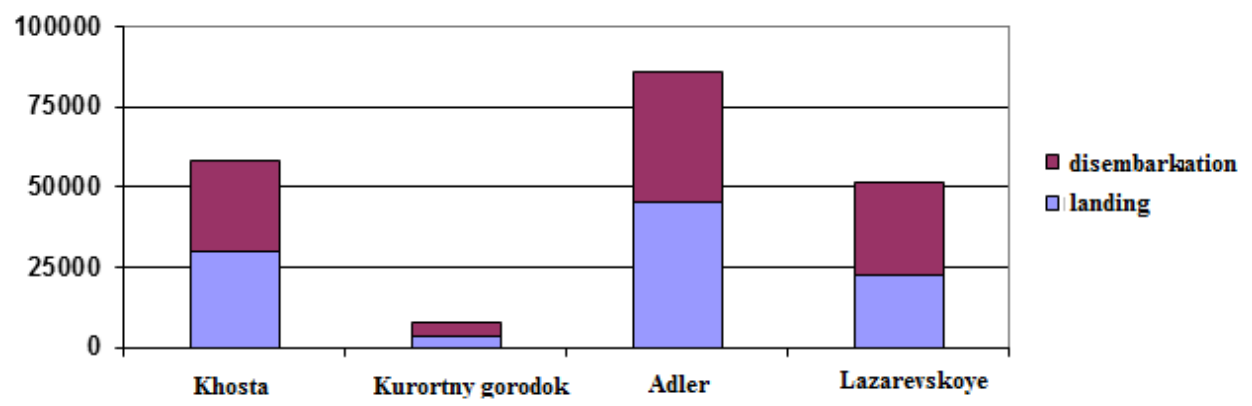

Fig. 1. Data on the capacity of some port moorings of the Sochi region in 1980-1990.

Sochi is the special territory of investment attractiveness and development of the infrastructure. It won this right to be called the resort center of Russia thanks to the geographical location and climatic conditions.

The principles of stability of the region and the prospect of its development as the resort agglomeration, largest in Russia, were formulated in the General plan of development of the city of 1986. These principles gained further development in the new General plan of 2009 and in offers on its development.

Need of further development of coastal transport infrastructure, including coastal transport, was noted in these Master plans of development of the city.

Need of restoration of sea passenger traffic within the coast of Greater Sochi is caused, first of all, with intensive development of tourism in Krasnodar Region, ensuring transport 
communication between settlements and activization of tourist activity in the region before and after holding the Olympic Games in 2014 and the FIFA World Cup in 2018.

Perspective development of coasting transportations around B. Sochi has considerable potential, and is connected, first, with development of tourism near Greater Sochi.

Besides, development of this segment assumes active measures for restoration of popularity of sea walks among tourists, including due to updating of the worn-out fleet.

Segments of the market of coastal shipping will make:

- walking transportations,

- regular transportations.

The forecast of the PriceWaterHouse Company, which was executed within development of justification of investments into development of the Sochi port, showed that the need for local passenger traffic by 2010 made more than 300 thousand people, and by 2020 respectively has to reach 700 thousand passengers a year.

The need for local passenger traffics is confirmed also by introduction in recent years to action of the Sochi-Novorossiysk, Sochi-Batumi and Sochi-Yalta line which several thousands of passengers a year use.

Besides, development of this segment assumes active measures for restoration of popularity of sea walks among tourists, including due to updating of the worn-out fleet.

According to the executed expected studies, at the basic scenario of development, by 2020 increase in a passenger turnover almost by 6 times, in comparison with 2008 is expected, and at the optimistic scenario of development of economy of Russia - almost by 10 times. It is possible to expect in 2020 achievement of a passenger traffic of the coastal marine transport at the level of 80-90 years (Fig. 2).

Creation of infrastructure for coastal sea passenger traffic and yachting along the Russian coast of the Black Sea is one of the important directions of development of recreational potential of a coastal zone of the Sochi region and all Black Sea coast of Russia. Such infrastructure will allow to diversify significantly recreational and tourist activity (tourism, hotel business, etc.). The section of reconstruction of transport infrastructure of the coastal cities and all region, including development of the coastal marine transport and yachting is available in the Federal program of development of the Black Sea coast of Russia and other documents [1, 9-10].

The program of reconstruction and creation of coastal infrastructure for restoration and operation of local passenger sea lines only on the Caucasian Black Sea coast of Russia assumes construction about 10 yacht harbors, restoration, reconstruction or construction more than 30 port points (moorings) along all coastal zone of the Black Sea coast of Russia $[1,5-8]$.

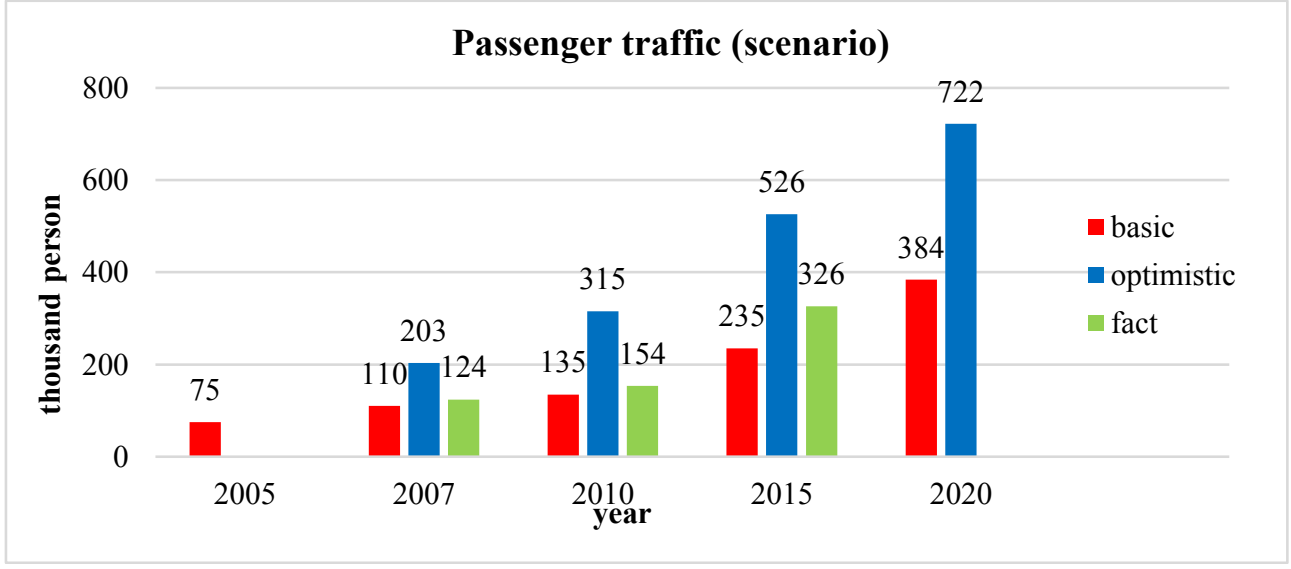

Fig. 2. The forecast of a passenger traffic on local coastal lines. 
Port points (moorings) represent bank protection hydraulic engineering constructions, considerable by the sizes. Their construction and operation can lead to essential impacts on the water environment in a coastal zone of the sea and an adjacent coastal zone, deformations of the coastline and a beach strip near the territory of piers, to deterioration of coastal waters.

It is necessary to predict these influences, to estimate ecological damages and to provide minimization of the corresponding integrated ecological damage to ensuring rational environmental management with preservation of the environment.

Prospects of creation of group of yacht harbors and port piers on the Black Sea coast of Russia (in total more than 30, including 15 in the Sochi region) according to the program of development of the tourism industry in the territory of Krasnodar Region and also that conditions of areas of construction are in many respects similar result in need of the solution of a problem of development of engineering decisions, damage assessment, both at a construction stage, and at the subsequent complex recreational operation of such objects.

The project of reconstruction and construction of 15 sea terminals of seaport of Sochi with creation of coastal infrastructure for restoration of local passenger sea lines certainly creates additional technogenic load of the environment in the region of Sochi and the adjacent territory [1-3, 8-9].

Detailed researches of possible consequences for an ecological situation in a coastal zone are necessary for adoption of ecologically focused administrative decision on realization of the planned economic and other activity connected with reconstruction of port points (moorings). Full assessment of possible adverse effects, assessment of ecological consequences, and development of measures for reduction and prevention of negative impacts on a coastal zone of the sea near port points is necessary [9-10].

\section{Prospects of development of coastal transport in the Sochi region and on the Black Sea coast of Russia}

Reconstruction of the passenger berthing and port facilities corresponding on planning, comfort and safety to the European standards is caused by the prospect of development of sea cruise and tourist passenger traffic provided in the concept of the General plan of development of the Sochi region [8]:

- intermodal transportations across all Black Sea;

- excursion transportations across the near coast;

- transport and distributive transportations of the having a rest tourists on beaches;

- pendular labor trips of persons between the port points of Sochi region.

Creation of the sea transport system for passenger traffic near Sochi assumes to transport along a northern and southern route. The port of Sochi has to become the center of change on routes and the stationing site of passenger fleet.

Federal State Unitary Enterprise "Rosmorport" (2013) at a stage "Justification of investments" before holding the 2014 Winter Olympics of developed and substantially realized the project "Reconstruction, construction of the port of Sochi with coastal infrastructure". The Program purpose is the creation of the international center of passenger and cruise traffic for ensuring reception of heavy-tonnage cruise vessels during the Olympic Games 2014 and development of tourism in the city". The project was carried out within the subprogram "Marine transport" as a part of the Federal Program "Modernization of the transport system of Russia (2002-2020 - 2030)".

To the main actions of reconstruction of the port of Sochi and adjacent territory of the coast, realized by the beginning of holding the Winter Olympic Games in Sochi in 2014, belonged:

- construction of deep-water moorings and new protective hydraulic engineering constructions for simultaneous reception of 6-8 heavy-tonnage multideck cruise vessels, 
- reconstruction of objects of port and water area with creation of yacht port and the corresponding infrastructure,

- reconstruction of port and coastal infrastructure for the purpose of creation of the international center of sea passenger traffic,

- arrangement of a marine on 500 berths,

- arrangement of the modern customs terminal at the international mooring,

- construction of the 2nd turn of check points between the southern gallery of port and the Beacon beach, creation of artificially educated territory of $200 \times 250 \mathrm{~m}$ between the southern pier of port and the central Sochi beaches, and then the 3rd turn of the admission of passengers,

- construction of the passenger terminal on the place of the cargo terminal with the expanded check point and the accelerated registration of passengers and their baggage,

- repair and restoration of the building of Marina,

- repair of engineering networks,

- reconstruction of hydraulic engineering constructions and coastal objects,

- reconstruction of eight moorings located along the seacoast of the region.

Reconstruction of five existing piers was carried out in settlements Lazarevskoye, Loo, Khosta, Kurortny gorodok and Adler at the first stage. In addition, construction of new piers on the place of the dismantled designs in points Dagomys, Matsesta and Imeretinka was carried out. The total amount of capital investments was about 10 billion rubles. Works were performed within implementation of the project "15 sea terminals of seaport of Sochi with creation of coastal infrastructure for implementation of sea passenger traffic (Imeretinka, the Southern cultures, Adler, the Kurortny gorodok, Kudepsta, Khosta, Matsesta, the Kurortny Park, New Sochi, Mamayka, Dagomys, Loo, Vardane, Lazarevskoye, Ashe)". This project was provided by the Resolution of the Government of the Russian Federation of 29.12.07 No. 991 "The program of construction of Olympic venues and development of the city of Sochi as mountain resort", of 11.06.08 No. 443 and the Resolution of the Government of the Russian Federation of 31.12.08 No. 1086 "About introduction of amendments to the resolution of the Government of the Russian Federation of 29.12.07 No. 991".

The schemes (fig. 3 and fig. 4, table 1) offered below cover all four administrative regions, practically all coast of Greater Sochi (except for the settlement of Ashe) and provides passenger traffics on the offshore section $82,9 \mathrm{~km}$ long.

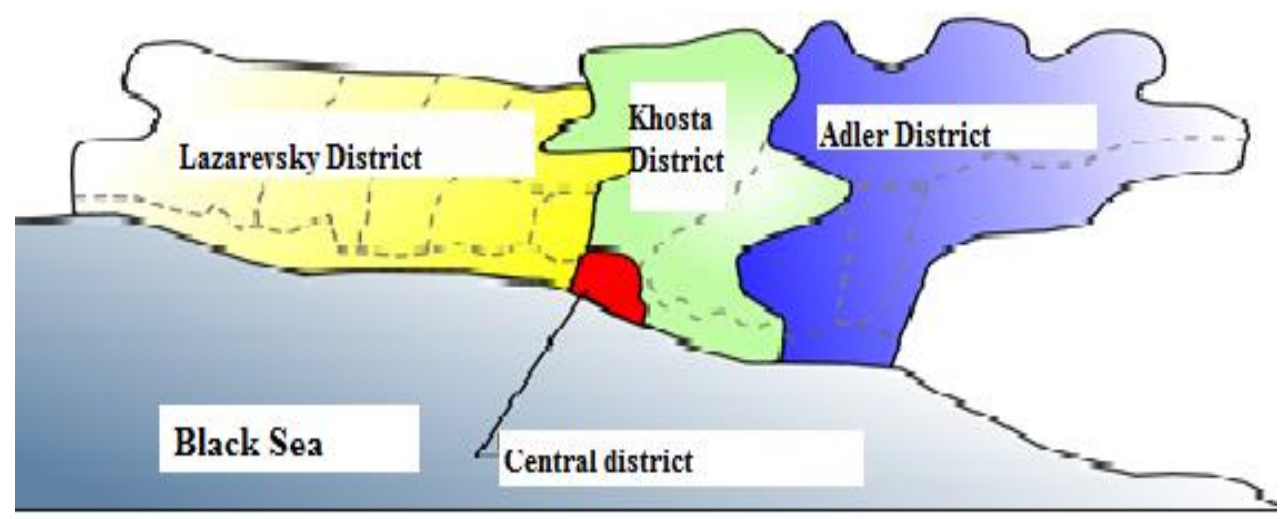

Fig. 3. Scheme of division into districts of Sochi 
Table 1. The main sites between port points (moorings) in the Sochi region

\begin{tabular}{|c|l|c|}
\hline № & \multicolumn{1}{|c|}{ Sea terminals } & Distance between terminals, km \\
\hline 1 & Lazarevskoye - Loo & 32,6 \\
\hline 2 & Loo - Dagomys & 8,1 \\
\hline 3 & Dagomys - Matsesta & 15,9 \\
\hline 4 & Matsesta - Khosta & 6,9 \\
\hline 5 & Khosta - Kurortny gorodok & 4,6 \\
\hline 6 & Kurortny gorodok - Adler & 9,3 \\
\hline 7 & Adler - Imeretinka & 5,5 \\
\hline & Total & 82,9 \\
\hline
\end{tabular}

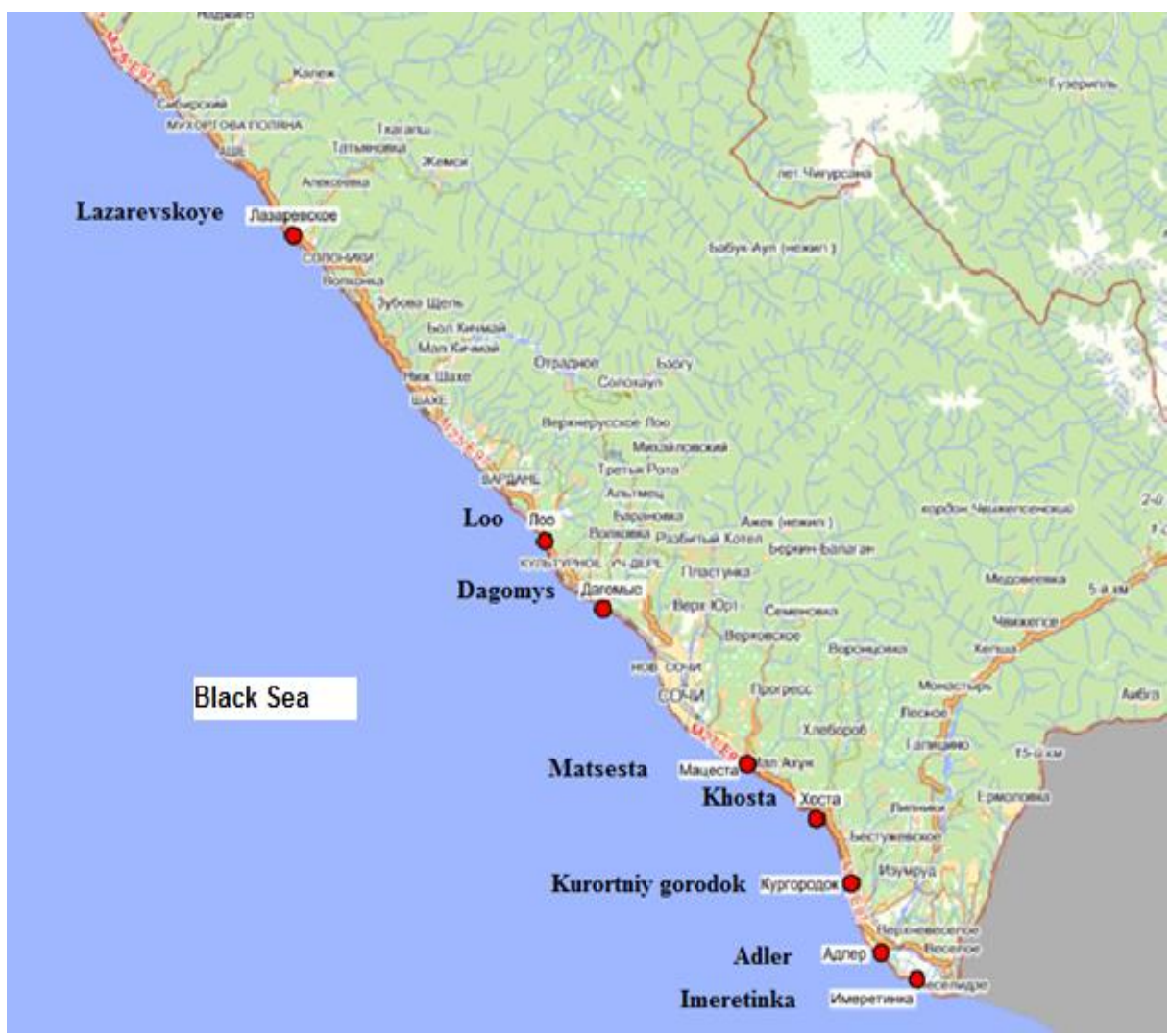

Fig. 4. Scheme of dislocation of port points (moorings).

The choice of eight sea terminals, prime for reconstruction, was caused by the following factors:

1) Five existing piers: Lazarevskoye, Loo, Khosta, Kurortny gorodok and Adler are in areas with the greatest population, the greatest density of an arrangement of recreational and tourist facilities (beaches, Spa-hotels, boarding houses, hotels). The railway stations showing points of stops of local, regional and interregional trains are located in these settlements.

2) At the choice of the first 5 objects of reconstruction of port points (moorings) also other indicators which characterize a condition of objects (Tab. 2) 
Table 2. Indicators of a condition of the territory near objects of reconstruction of port points.

\begin{tabular}{|c|c|c|c|c|c|c|c|c|}
\hline Name of port poin & 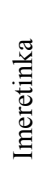 & $\frac{\bar{c}}{\bar{z}}$ & 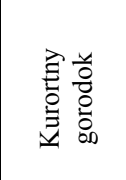 & 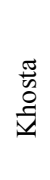 & $\begin{array}{l}\text { 苟 } \\
\text { 品 } \\
\text { 芯 }\end{array}$ & $\begin{array}{l}\overbrace{\tilde{\Xi}}^{\infty} \\
\stackrel{0}{0} \\
\tilde{\Xi}\end{array}$ & $\stackrel{8}{\circ}$ & 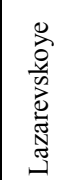 \\
\hline Existence of the river & - & - & - & - & - & yes & - & - \\
\hline \multirow[t]{2}{*}{ Existence of water outlets } & - & - & - & - & - & - & - & - \\
\hline & - & - & $1000 \mathrm{~mm}$ & - & - & - & - & - \\
\hline \multirow{2}{*}{$\begin{array}{l}\begin{array}{l}\text { Existence of releases of the storm water } \\
\text { drainage system } \\
\text { Quantity }\end{array} \\
\end{array}$} & - & - & yes & - & - & - & - & - \\
\hline & - & - & 2 & - & - & - & - & - \\
\hline \multirow{2}{*}{$\begin{array}{l}\text { Existence of the pebble beach } \\
\text { width }\end{array}$} & - & yes & yes & - & - & yes & yes & yes \\
\hline & - & $\begin{array}{c}30-80 \\
\mathrm{~m}\end{array}$ & $3-7 \mathrm{~m}$ & - & - & $50 \mathrm{~m}$ & $45 \mathrm{~m}$ & $18 \mathrm{~m}$ \\
\hline Existence of inhabited constructions & - & yes & yes & yes & - & yes & yes & yes \\
\hline Existence of coastal constructions: & - & yes & yes & yes & yes & - & yes & yes \\
\hline reinforced concrete the beach - groines & - & 2 & 2 & - & - & - & - & - \\
\hline piers & - & 1 & 1 & 1 & - & - & yes & yes \\
\hline alongshore wall for reflection of waves & - & 1 & 1 & 1 & 1 & - & yes & yes \\
\hline Existence of additional bank protection & - & - & $\begin{array}{l}\text { sketch of } \\
\text { reinforced } \\
\text { concrete } \\
\text { blocks }\end{array}$ & - & $\begin{array}{l}\text { sketch of } \\
\text { reinforced } \\
\text { concrete } \\
\text { blocks }\end{array}$ & - & - & - \\
\hline
\end{tabular}

In earlier existing system of local sea messages these piers were basic and accepted all types of passenger ships of coastal swimming, including high-speed hydrofoils.

The persons live in Lazarevskoye District (the existing piers moorings Lazarevskoye, Loo, Dagomys) more than 65,2 thousand. According to official figures about quantity of beds of subjects to accommodation of tourists, the area at a time can accept more than 15 thousand vacationers, from them 8 thousand - Dagomys. The area is most attractive to tourists; excursions on falls, caves, and gorges are organized here). The most northern in the world a tea plantation is located in the area.

More than 150 thousand people live in the Central district (Mamayka pier mooring, moorings in the port of Sochi). Largest hotels are located in the area, there are more than 15 thousand beds for accommodation of tourists.

The population of the Area of Khosta makes more than 70 thousand persons. Here piers Matsesta and Khosta are located. More than 20 thousand beds in subjects to accommodation of tourists are available in this area.

The unique balneological resort is located in the settlement of Matsesta. The building sea the station was reconstructed prior to the 2014 Winter Olympics of. It is located near the dismantled mooring Matsesta.

Piers Kurortny gorodok, Adler, Imeretinka are located in Adler District of Sochi. Here more than 80 thousand persons live. Quantity of beds on subjects to accommodation of tourists - more than 20 thousand. The dolphinarium, two aqua parks, the arboretum, largest in Europe, apery also settle down in this area.

Construction of four large Olympic venues is carried out near Imeretinka. The large number of subjects to accommodation of tourists is here too located and new port point (mooring) has to be equipped.

Reconstruction of five first port points (moorings) within the program [1, 5, 10] it was carried out prior to the Winter Olympic Games.

Piers Lazarevskoye, Loo, Khosta, Kurortny gorodok and Adler were characterized by considerable physical wear before reconstruction. They were in critical condition, were not serviceable and were almost taken out of service. 
The progressing destructions of elements of designs worsened an ecological condition of the coast and constituted serious danger to vacationers.

The cost of reconstruction of these piers was commensurable with costs of their dismantling.

Piers Dagomys, Matsesta and Imeretinka were constructed on sites of earlier settling down designs, which were dismantled in the 90th in connection with final fracture.

The post-Olympic prospects and development of the resort of Sochi in general are impossible without accurate and comfortable reception of "sea" tourists. Therefore, development of the Sochi port, further reconstruction of all port points (moorings) and all related infrastructure, by analogy with other world resorts, is a necessary condition of development of the coastal marine transport and includes the following features of reconstruction:

- strengthening in Europe advertising of the resort town of Sochi as center not only recreational, beach and mountaineering, but also sea tourism,

- acquisition of highly comfortable and high-speed sea average vessels,

- reconstruction located along the sea coast of the region and along all Black Sea coast of Russia of moorings for service of local coastal transport (boats, yachts, pleasure crafts, coastal transport).

For implementation of offers on restoration of local passenger sea lines, it is provided:

- at the first stage (for the Sochi region) - full complex reconstruction of all 15 port point in Sochi (Imeretinka, Southern cultures, Adler, Kurortny gorodok, Kudepsta, Khosta, Matsesta, the Kurortny park, New Sochi, Mamayka, Dagomys, Loo, Vardane, Lazarevskoye, Ashe), with creation of the corresponding coastal infrastructure. Partially on separate port point and moorings on the site from Sochi to Adler, works on reconstruction were performed prior to holding the 2014 Winter Olympics of on projects of Federal State Unitary Enterprise Rosmorport. Five port-point (piers) were partially reconstructed prior to the Olympic Games;

- at the second stage - acquisition high-speed (the sea taxi) and pleasure passenger ships, including on air wings.

Construction objects in port point:

- moorings of local lines;

- navigation situation;

- engineering networks;

- commercial objects for service of passengers (pavilions of service of passengers, caférestaurants, shops, etc.).

Placement of new moorings is supposed to be organized on the place of the moorings, which were earlier existing and destroyed for the last decades. Piers have to be taken out on natural depths. Constructive and architectural concepts can be various.

Examples of the possible constructive solutions for port points of the Sochi region proposed in projects of Federal State Unitary Enterprise "Rosmorport" are given in drawings below (fig. 5).

At construction of port points and piers, it is possible to carry the following to the main engineering requirements:

- the port navigation "Column" sign has to be established on approaches in the center of a head part of each pier for navigation safety;

- borders of the operational water area of moorings from the coast have to be protected with the floating warning signs (buoys sea small);

- mooring dimensions in addition to aids to navigation have to be designated by the light background created by the lighting fires established on a pier;

- it is expedient to carry out works on construction of sea terminals (piers) by forces of one general contract construction organization ("General contractor") which is defined by "Customer" as a result of the tender (contract) auction [10]. 

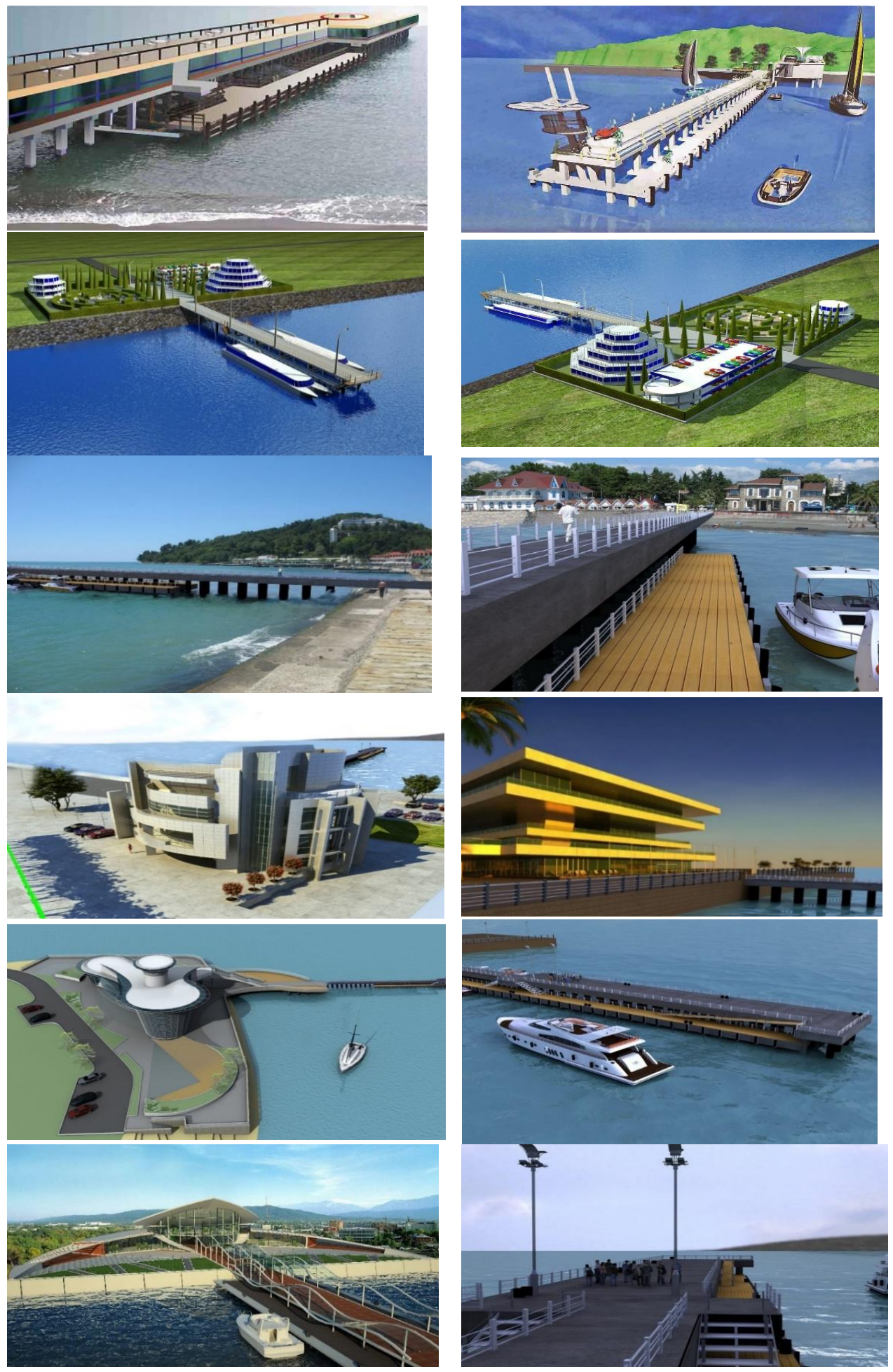

Fig. 5. Drafts of engineering decisions for port points (moorings). 
The organization of construction has to provide production of installation and construction works generally in the spring and summer period (the period of smaller number of storm days) with application of modern means of mechanization of productions, with implementation of all requirements and recommendations about works during this period of time, nature protection requirements and requirements for safety of work. Feature of construction during this period is that usually port points (moorings) settle down near beach territories.

Duration of construction of each of piers should not exceed 80-90 days. The expected cost of installation and construction works on each new or reconstructed pier on average can be 130 million rubles.

Acquisition of highly comfortable and high-speed sea average vessels is also important stage in development of local coastal navigation. Several port points (moorings) already function after reconstruction. The irregular movement of "Comet" hydrofoils on a route of Sochi-Novorossiysk-Yalta and Sochi-Batumi began. However, the vessels of outdated types operated in a coastal zone. They are insufficiently comfortable and have the big term of their operation.

Examples of new types of vessel for the organization of coastal shipping in the region can be similar provided on figures 6 and 7 .

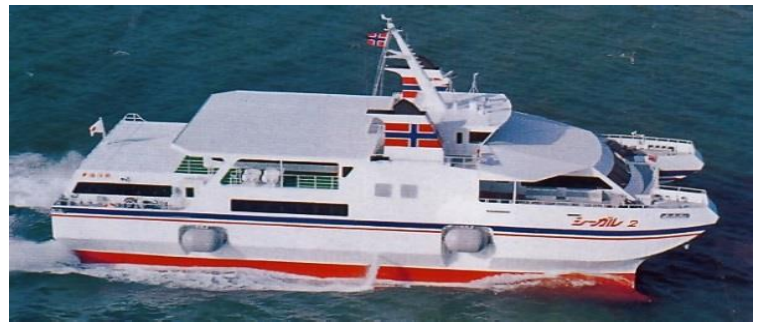

Fig. 6. Pleasure craft. Passenger capacity - 60 grazed (length $=19,5 \mathrm{~m}$; width is $=9,0 \mathrm{~m}$; draft is $=0,7 \mathrm{~m}$ ). Speed -22 knots.

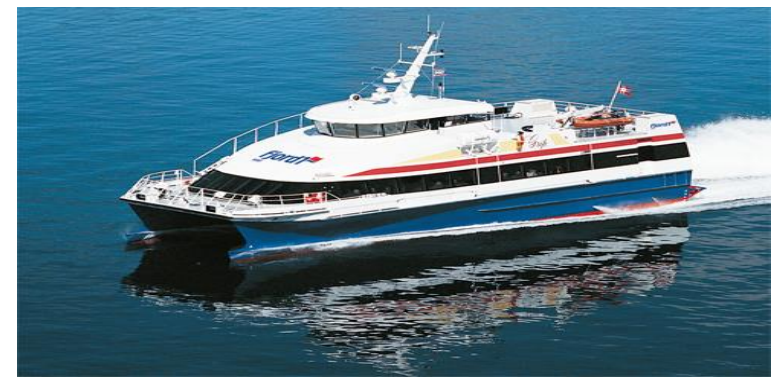

Fig. 7. Liner. 60 - 150 grazed passenger capacity (length $=34,5 \mathrm{~m}$; width $=8,4 \mathrm{~m}$; draft $=1,7 \mathrm{~m}$ ). Speed $25-41$ knot.

Restoration of sea passenger traffic within Greater Sochi is a basis for the subsequent creation of system of sea messages on local lines on all Black Sea coast of Russia.

\section{Problems of an environmental protection at reconstruction and development of coastal sea transport infrastructure in the Sochi region}

Because the project of reconstruction existing and of constructions of new piers will be carried out in a coastal zone of the sea, additional researches of questions of assessment of 
impact on the surrounding environment and its protection against potential negative impacts are necessary.

Construction and further use of such constructions will lead to impacts on the water environment. Therefore, assessment of impacts on the environment for the purpose of determination of ecological admissibility of such objects is necessary [3-5, 8-10].

Achievement of this purpose requires the solution of the following tasks:

- to define types and degree of danger of all potential impacts on the coastal environment at construction and the subsequent operation of port piers;

- to assess the economic, environmental and social impacts of these influences;

- to minimize influences and possible dangers as a result of this activity;

- to make ecologically focused management and engineering decisions.

Construction of these objects can cause the following impacts on the environment at a construction stage:

- deformations of a relief of a seabed;

- decrease in illumination of sea water due to increase in turbidity when carrying out on separate objects of dredging works and construction of constructions of piers and moorings;

- increase in noise level and the vibrations owing to operation of the construction equipment providing and small size vessels, the equipment for construction of moorings;

- pollution of a suspension, ground rainfall owing to leak of oil products from vessels and technical means involved in construction;

- unauthorized dumping and leak of technical, wash and household waters from vessels and technical means;

- possible intake of pollutants from ground rainfall during the dredging works;

- the dynamic loads arising during the operation of the construction equipment, etc. [3-5, 8-10].

Major issue at implementation of the program of reconstruction and construction of port points (piers) is the version of the decision at which the organization of construction provides works generally in the spring and summer period (the period of smaller number of storm days).

Feature of construction during this period is that usually port points and piers are located near beach territories. Therefore, a part of the beach territory and coastal water area near construction objects will be withdrawn from recreational activity when carrying out such works. Besides, negative impact on rest of tourists will be had by increase in noise level and the vibrations owing to operation of the construction equipment providing and small size vessels, pollution of water resources near the coast, etc.

Separate piers will influence also significantly and a picture of circulation of currents in a coastal zone at an operational phase. Piers act from the coast towards the sea and can partially change structure of a current within the water area and cause development of own local circulation and emergence of stagnant zones in the back of constructions. Hydraulic engineering constructions of piers can also cause changes in a coastline configuration, partially blocking an alongshore stream of deposits [3-5, 8-10].

The impact on the water environment made in the course of construction and functioning of port points (piers) depends on many natural and technogenic factors, such as

- hydro and meteorological characteristics of the area of construction,

- particle size distribution of material of a seabed,

- extent of background pollution of ground material,

- existence of beaches,

- longshore flow of deposits,

- erosion by waves of the coast,

- background pollution and sources of pollution of sea water,

- location of a port-point in the plan, 
- a configuration and types of a hydrotechnical structure and a design of port-point and the mooring,

- types of works on dredging (alignment of a bottom under constructions, the depth of the dredging, etc.)

- technologies and volumes of the work in the course of construction,

- terms of performance of construction works,

- the used dredging equipment,

- schedules of production of construction works,

- types of the used equipment at construction,

- recreational activity near construction area, etc.

The large number of such influencing factors demands their detailed generalization and systematization.

It is necessary to predict these influences before implementation of the project of reconstruction and construction of port-points and piers, to count the corresponding integrated ecological damages and to provide their minimization for ensuring rational environmental management with preservation of the environment.

\section{Conclusions}

Implementation of the project of reconstruction and construction of 15 sea terminals of seaport of Sochi with creation of coastal infrastructure for the purpose of restoration of local passenger sea lines will contribute to the further development of tourism in the region, to formation of an image of Sochi as center both recreational, and mountain, and sea tourism.

Conditions of use of coastal territories, restoration and further development of coastal transport infrastructure have to be carefully and are in addition investigated and defined in updating of the Concept of development of the General plan during the post-Olympic period.

However, this project certainly creates additional technogenic load of the environment in the region. Therefore, careful studying minimization of negative consequences from its realization is required.

Piers for reception of passenger ships with a bilateral arrangement of moorings with the lowered platform have to be created for ensuring regular passenger traffic within Greater Sochi. Construction and reconstruction of objects of the coastal marine transport is an important social and economic task.

Additional researches of possible consequences are necessary for an ecological situation in a coastal zone at implementation of this project. They have to be executed for adoption of ecologically focused administrative decision on realization of the planned economic and other activity near port points (piers) by means of more detailed assessment of ecological consequences of construction and operation, development of measures for reduction and prevention of negative impacts on a coastal zone.

The project has the high social importance. Restoration of local passenger traffics not only will significantly reduce the existing transport tension in the region, but also, undoubtedly, meets the requirements of improvement of the coast of Greater Sochi.

Restoration of sea passenger traffic within Greater Sochi also is a basis for creation of system of sea messages on local lines and on all Black Sea coast of Russia.

As a result of the embodiment of offers of development of the coastal marine transport, yachting, restoration and development of system of port points (moorings) on the Black Sea coast of Russia the following results can be achieved [3-5, 8, 10]:

in TOWN PLANNING: high-quality improvement of functional use of a coastal recreational zone; change of architectural appearance of the recreational urbanized complexes in a coastal zone entering into it of essentially new elements; 
in the COASTAL MARINE TRANSPORT: creation of the region of intensive yachting, coasting swimming, interdistrict sea transport freight and passenger traffic as element of the Black Sea tourism;

in ECONOMY: increase in tourist appeal of the region of a wide range; attraction of investments on the coast; stimulation of development of new branches of economy in the region;

in the SOCIAL SPHERE: creation of new jobs in various city spheres having the relation to service of the coastal marine transport: construction, consumer services, public catering, etc.; development of peripheral areas of the coast; full involvement of recreational resources of the region.

Only system approach to implementation of the program of coastal transport will contribute to the complex development of the Black Sea coast of Russia as region with the wide list of services for sea tourism.

\section{References}

1. E.V. Bondareva, I.G. Kantarzhi, Yu.I. Drejzis, Stroitel'stvo yahtennyh portov (marin) na Chernomorskom poberezh'e RF i problemy ehkologii (Nauka Kubani, Krasnodar, 2008)

2. A.A. Korotkij, V.S. Kotel'nikov, Ehkologiya i bezopasnost' J., S-Peterburg: 2(58), (2009)

3. E. Bondareva, N. Grishin, Yu. Dreizis, I. Kantardgi, Environmental impact assessment of the developed yacht-ports along the Russian Black Sea coast, Proceedings of the Seven International Conference «COPEDEC VII» 197, 13 (2008)

4. E. Bondareva, Yu. Dreyzis, I. Kantardgi, The Yachting Development at Sochi Region and Problem of CZM, Proc. of MED \& Black Sea ICM 08 International Conference 4 (2008)

5. Yu.I. Drejzis, Sb. trudov $V$ mezhdunarodnoj nauchnoj konferencii «Integraciya partnerstvo i innovacii v stroitel'noj nauke i obrazovanii» (RIC MGSU, Moskva, 2016)

6. Yu.I. Dreizis, Geography, GeoSciences, Environmental Science \& Disaster Management, 16(5), 37 - 56 (2017)

7. Yu.I. Dreyzis I.G. Kantardgi, Proc of the Thirteenth International MEDCOAST Congress on Coastal and Marine Sciences, Engineering, Management and Conservation - MEDCOAST 2017 1, 13-25 (2017)

8. Yu. Dreizis, I. Potashova, MATEC Web of Conferences 17005007 (2018)

9. E.V. Bondareva, I.G. Kantarzhi, Materialy XXII Mezhdunarodnoj beregovoj konferencii «Problemy upravleniya i ustojchivogo razvitiya pribrezhnoj zony morya» (OOO «Ehdart print», Krasnodar, 2007)

10. Yu.I. Dreyzis, I.G. Kantarzhi, V.V Vaytman, L.V. Prokhoda-Shumsky, E.V. Bondareva, V.S. Shevtsov, Avtomatizirovannye metody otsenki vliyaniya yakht-portov (marin) na beregovuyu zonu morya. Nauchnyy otchet (VNIITS, Moskva, 2010) 